\title{
Vitamin C as a Supplementary Therapy in Relieving Symptoms of the Common Cold: A Meta-Analysis of 10 Randomized Controlled Trials
}

\author{
Li Ran, ${ }^{1,2}$ Wenli Zhao, ${ }^{3}$ Hongwu Wang, ${ }^{4}$ Ye Zhao $\mathbb{D}^{5},{ }^{5}$ and Huaien Bu $\mathbb{D}^{4}$ \\ ${ }^{1}$ Graduate School, Tianjin University of Traditional Chinese Medicine, Tianjin 300193, China \\ ${ }^{2}$ Department of Occupational and Environmental Health, School of Health Sciences, Wuhan University, Wuhan 430071, China \\ ${ }^{3}$ Liver Center, Saga University Hospital, Saga University, 849-8501, Japan \\ ${ }^{4}$ School of Health science and Engineering, Tianjin University of Traditional Chinese Medicine, Tianjin 300193, China \\ ${ }^{5}$ Qingdao Academy of Traditional Chinese Medicine, Shandong University of Traditional Chinese Medicine, Qingdao 266112, China
}

Correspondence should be addressed to Ye Zhao; zhaoye@sdutcm.edu.cn

Received 16 January 2020; Revised 12 September 2020; Accepted 18 September 2020; Published 10 October 2020

Academic Editor: J rgen B nger

Copyright ( 92020 Li Ran et al. This is an open access article distributed under the Creative Commons Attribution License, which permits unrestricted use, distribution, and reproduction in any medium, provided the original work is properly cited.

\begin{abstract}
Aim. To investigate whether vitamin C performs well as a supplemental treatment for common cold. Method. After systematically searching through the National Library of Medicine (PubMed), Cochrane Library, Elsevier, China National Knowledge Infrastructure (CNKI), VIP databases, and Wanfang databases, 10 randomized controlled trials were selected for our metaanalysis with RevMan 5.3 software. Published in China, all 10 studies evaluated the effect of combined vitamin C and antiviral therapy for the treatment of common cold. Results. The total efficacy ( $\mathrm{RR}=1.27,95 \%$ CI $(1.08,1.48), P=0.003)$, the time for symptom amelioration $(\mathrm{MD}=-15.84,95 \% \mathrm{CI}(-17.02,-14.66), P<0.00001)$, and the time for healing $(I, 95 \% \mathrm{CI}(-14.98,-4.22)$, $P=0.0005)$ were better with vitamin $C$ supplementation than with antiviral therapy alone. Conclusions. Vitamin $C$ could be used as a supplementary therapy along with antiviral regimens to relieve patients from the symptoms of common cold.
\end{abstract}

\section{Introduction}

Common cold (also known as cold), which is a common and frequent disease, is an upper respiratory tract infection (URTI) mainly caused by viruses that includes uncomfortable symptoms like stuffy or runny nose, coughing or sneezing, sore throat, chills, fever, and headache $[1,2]$.

Common cold is self-limited and lasts between seven and ten days [3]. Generally, it is unnecessary to administer any antiviral medicine to treat cold, for the symptoms are usually mild and there is still no effective antiviral treatment [2]; however, when it progresses quickly and presents with severe symptoms, over-the-counter (OTC) medications (nasal decongestants, antihistamines, cough suppressants, nonsteroidal antipyretic analgesics, and expectorants) should be promptly administered to relieve patients from symptoms. Although common cold itself is not a threat under normal circumstances, it still imposes a substantial economic and societal burden in two ways.

The incidence of common cold is high. As indicated in some reports, children suffer an average of 6 to 10 colds per year (up to 12 colds for school children), in contrast to adults, who experience only 2 to 5 colds annually, each lasting an average of 9 days $[4,5]$. Due to the high incidence, absence from work and reduction of work capacity caused by common cold inflict great economic damage. Sweden bore an estimated annual total productivity loss of 2.7 billion Euros (US $\$ 3.17$ billion), and the mean loss of productive capacity was at 5.1 days per employee per year [6]; in addition, in the United States, 22 to 189 million school days and 20 to 126 million workdays are lost annually $[7,8]$, and the economic burden is approximately $\$ 40$ billion (95\% confidence interval, $\$ 31.2$ to $\$ 48.0$ billion) [9]. After common cold infection, physician visits and prescription medications resulted 
not only in unnecessary medical waste but also in increased economic pressures. Before 2000, approximately 27 million physician visits were made annually, and the cost to purchase OTCs for common cold and other viral respiratory infections was almost $\$ 2$ billion; in 2013, the cost of OTCs for common cold alone was up to $\$ 2.9$ billion dollars [10]. According to the data from the World Health Organization (WHO) in 2013, common cold led to 75 to 100 million physician visits at a conservative cost of $\$ 7.7$ billion per year in the United States, of which, $\$ 400$ million were spent for prescription medications. At the same time, in the United Kingdom, the medical cost of OTCs for coughs and cold reached 500 million pounds ( $\$ 644.35$ million) per year [11]. While there is no economic loss estimation due to common cold in China, consumption of cold medications in the retail market reached 9.2 billion Chinese Renminbi (RMB, US \$379.08 million) in 2008 alone [12].

Symptoms such as fever, cough, and headache usually subside within a few days without any serious complications; however, severe colds, particularly comorbid with meningitis or lower respiratory tract infection (LRTI) such as pneumonia could be fatal if untreated, especially for individuals with compromised immune system [13]. Common cold (or respiratory infection) is the root of all diseases, which suggests that untreated cold may lead to LRTIs and diseases in other organs. According to the statistics in China, there is a close relationship between common cold and the onset, aggravation, and relapse of chronic bronchitis-an estimated $56.4 \%$ of new chronic bronchitis cases have a history of cold, and $65.4 \%$ of acute chronic bronchitis attacks are associated with cold. In addition, almost one-third of pneumonias develop from cold [14]. Additionally, $5 \%$ of the seasonal increase in mortality associated with cardiovascular disease is related to respiratory infection $[15,16]$.

Over 200 serologically different viral strains are responsible for human URTIs, with rhinoviruses being the most common [17]. Although $70 \%$ to $80 \%$ of common cold cases are caused by viruses, there is still a small percentage caused by bacteria. As a result, we consider a misuse of antibiotics and antiviral therapy in treating the common cold or URTIs clinically [18]. Through this meta-analysis, we aim to evaluate the efficacy of vitamin $\mathrm{C}$ treatment and advocate for a rational use of medicine.

\section{Methods}

2.1. Search Strategy. Two independent reviewers systematically searched in PubMed, Cochrane Library, Elsevier, China National Knowledge Infrastructure (CNKI), VIP databases, and Wanfang databases, from their earliest records through December 2019. The following key words were used: common cold, URTI, Vitamin C, and ascorbic acid. Subsequently, studies were screened and selected according to the guidelines for Meta-Analyses and Systematic Reviews of Observational Studies (MOOSE) [19] and Preferred Reporting Items for Systematic Reviews and Meta-Analyses (PRISMA) [20].

\subsection{Inclusion Criteria}

2.2.1. Study Pattern. Using vitamin $\mathrm{C}$ as a therapeutic technique with antiviral therapies, all randomized controlled tri- als (RCTs) related to common cold were included in our study. Studies were published in English or Chinese.

2.2.2. Study Participants. We selected study participants who were diagnosed with common cold based on laboratory examination, clinical signs, and reported symptoms. More specifically, common cold is presenting with catarrhal symptoms, such as stuffy nose, runny nose, sneezing, and coughing. Then, identification of viruses and exclusion of other pathogenesis was conducted by viral culture, antigen detection, and polymerase chain reaction (PCR).

2.2.3. Intervention. Through literature search, we detected a trend of prescribing antiviral drugs in China, unlike Europe and the United States, which may be caused by differences in patient health and national medical practices. Generally speaking, almost all RCTs were conducted comparing vitamin $\mathrm{C}$ and placebo in Europe and the United States, while the others were comparing vitamin $\mathrm{C}$ in combination with antiviral therapies versus antiviral therapies alone in China. Based on the distinct intervention that we regarded as an explanation possibly for the strong clinical heterogeneity, the treatment group must have received intervention with vitamin $\mathrm{C}$ as well as antiviral therapy, while the control group received antiviral therapy only.

\subsubsection{Outcome}

(1) Efficacy Criteria. The efficacy criteria were (1) total effective rate, (2) average time for symptom amelioration, and (3) average time for healing.

(2) Adverse Events. Any abnormal signs and symptoms during treatment were regarded as adverse events.

2.3. Exclusion Criteria. Exclusion criteria were (1) duplicated articles; (2) nonclinical trials, such as animal testing; (3) nonRCTs, such as case reports and experiences, theory research, and reviews; (4) the assessment of vitamin $\mathrm{C}$ in the prevention of common cold; and (5) treatment group did not undergo combination therapy with vitamin $\mathrm{C}$ and antiviral medication.

2.4. Quality Assessment. Quality assessment was performed on the following items according to Cochrane Collaboration's tool for bias risk: (1) random sequence generation, (2) allocation concealment mechanism, (3) blinding of participants and personnel, (4) blinding of outcome assessment,(5) incomplete outcome data, (6) selective reporting, and (7) other biases. The outcomes were independently evaluated by two researchers as high risk, unclear, and low risk.

2.5. Statistical Analysis. For the "incidence" parameters like efficacy and adverse events, the total number of participants and different events in the treatment and control groups were extracted. However, for the "severity" parameters, such as average time for symptom amelioration and average time for healing, the mean values with standard deviation (SD) were calculated. All parameters were entered in Review Manager 5.3 software for analysis with the corresponding 95\% confidence intervals $(\mathrm{CI})$. 


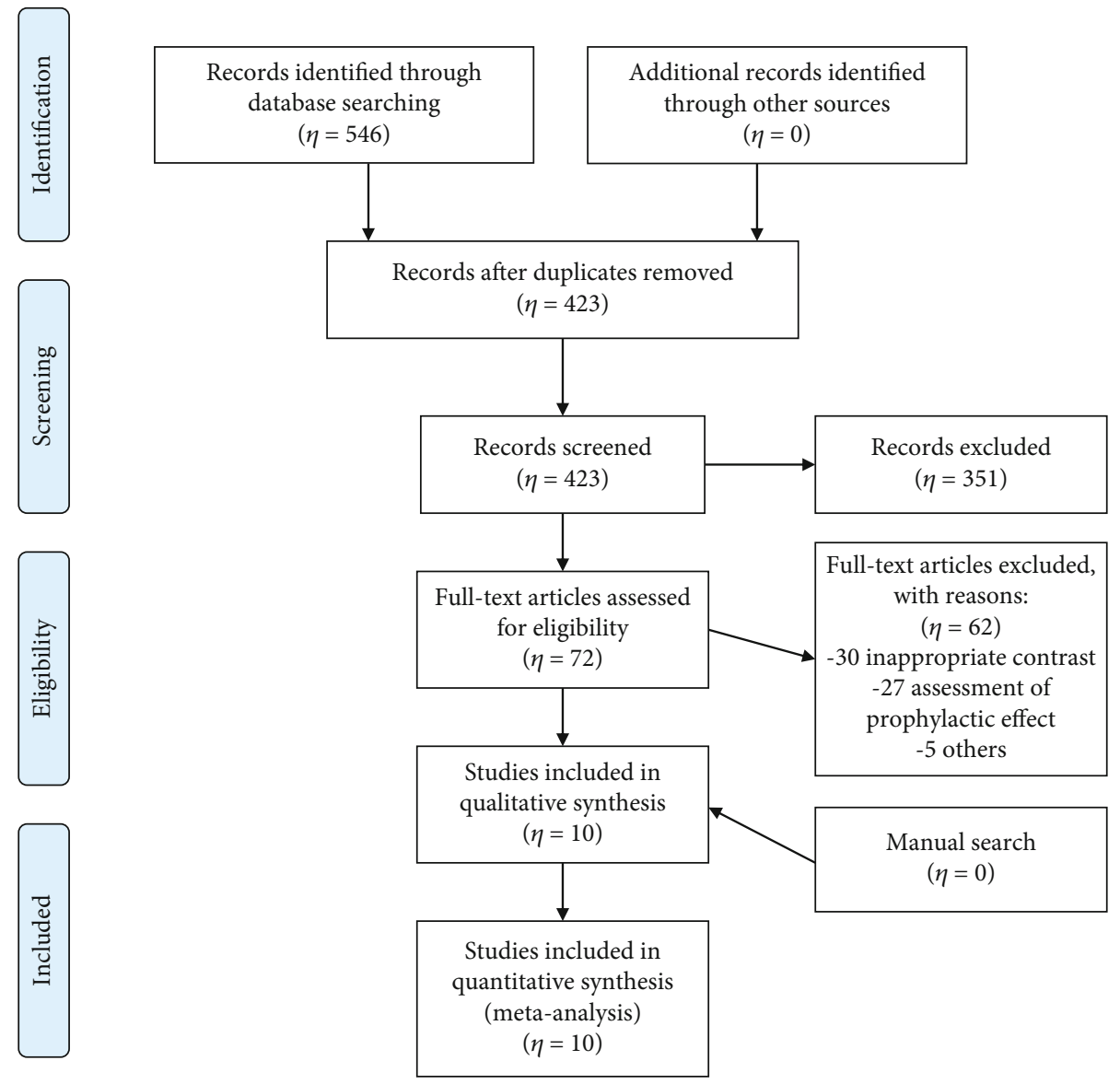

FIGURE 1: Study selection procedure.

Heterogeneity was detected by the Chi-squared test and inconsistency- $(I-)$ squared statistics. In our meta-analysis, the random-effects model was used when $P \leq 0.05$ or $I^{2}>$ $50 \%$; otherwise, the fixed-effects model was preferred.

\section{Results}

3.1. Study Selection. Of the 546 RCTs, 123 duplicate trials identified in the PubMed, Cochrane Library, Elsevier, CNKI, VIP, and Wanfang data were excluded. Additional 351 RCTs were excluded based on titles and abstracts, and 62 were excluded after full-text review. The study selection procedure is outlined in Figure 1.

3.2. Study Characteristics. As shown in Table 1 , the 10 selected RCTs recruited patients that were treated for common cold with a combination of vitamin $C$ and antiviral therapy or antiviral therapy alone. These studies included 1048 patients and were conducted between 2007 and 2019.

3.3. Quality of the Included Studies. Table 2 shows the quality of included studies, with the risk of bias based on the Cochrane Handbook. All studies were 100\% completed and had no bias in selective reporting, but none had any description about allocation concealment, blinding of participants and personnel, blinding of outcome assessment, or other bias. Only three articles $[23,25,29]$ demonstrated that a random sequence was generated with random number tables, and there was no detailed information in the remaining seven.

\subsection{Meta-Analysis of Outcome Criteria}

3.4.1. Total Effective Rate. The total effective rate was reported in 10 RCTs [21-30] in China, involving 1048 participants. We performed subgroup analyses to make sense whether the effective rate is different between viral infections and unexplained infections (bacterial or viral infection). According to the outcomes shown in Figure 2, vitamin $\mathrm{C}$ combined with antiviral therapy was significantly more effective than antiviral therapy alone in viral infections $(\mathrm{RR}=1.27$ , 95\% CI (1.08, 1.48), $P=0.003)$; vitamin C combined with antiviral therapy showed no difference to antiviral therapy alone in bacterial or viral infections $(R R=1.33,95 \% \mathrm{CI}$ $(0.92,1.93), P=0.12)$.

3.4.2. Average Time for Improving. The average time for symptom amelioration was reported in five trials [21, 23$25,27]$ involving 440 patients. No heterogeneity was observed (Cochrane $Q$ test $=3.69, \mathrm{df}=4, P=0.45, I^{2}=0 \%$ ), and the vitamin $\mathrm{C}$ group supplementation performed better 
TABLE 1: Characteristics of included studies for the comparison of vitamin C plus antiviral therapy with antiviral therapy alone.

\begin{tabular}{|c|c|c|c|c|c|c|c|c|}
\hline \multirow{2}{*}{ Author } & \multirow{2}{*}{ Year } & \multirow{2}{*}{$\begin{array}{c}\text { Sample } \\
\text { size }(T / C)\end{array}$} & \multicolumn{2}{|c|}{$\begin{array}{c}\text { Gender } \\
\text { (male/female) }\end{array}$} & \multirow{2}{*}{ Age (T/C, year) } & \multicolumn{2}{|c|}{ Intervention } & \multirow{2}{*}{ Outcome } \\
\hline & & & Treatment & Contrast & & Treatment & Contrast & \\
\hline Fan [21] & 2016 & $50 / 50$ & $\begin{array}{c}\text { Not } \\
\text { reported }\end{array}$ & $\begin{array}{c}\text { Not } \\
\text { reported }\end{array}$ & Not reported & $\begin{array}{l}\text { Antiviral therapy } \\
\text { + vitamin C }\end{array}$ & $\begin{array}{l}\text { Antiviral } \\
\text { therapy }\end{array}$ & $\begin{array}{l}\text { Total efficacy + symptom } \\
\text { improvement }+ \text { side effects }\end{array}$ \\
\hline $\begin{array}{l}\text { Gao and } \\
\text { Wang [22] }\end{array}$ & 2014 & $130 / 130$ & $69 / 61$ & $72 / 58$ & Not reported & $\begin{array}{l}\text { Antiviral therapy+ } \\
\text { vitamin } C\end{array}$ & $\begin{array}{l}\text { Antiviral } \\
\text { therapy }\end{array}$ & Total efficacy \\
\hline $\operatorname{Li}[23]$ & 2017 & $33 / 33$ & $15 / 18$ & $16 / 17$ & $\begin{array}{l}21.84 \pm 1.02 \\
/ 21.68 \pm 1.10\end{array}$ & $\begin{array}{l}\text { Antiviral therapy } \\
+ \text { vitamin C }\end{array}$ & $\begin{array}{l}\text { Antiviral } \\
\text { therapy }\end{array}$ & $\begin{array}{c}\text { Total efficacy }+ \text { symptom } \\
\text { improvement }\end{array}$ \\
\hline $\mathrm{Wu}[24]$ & 2015 & $48 / 48$ & $\begin{array}{l}\text { Not } \\
\text { reported }\end{array}$ & $\begin{array}{l}\text { Not } \\
\text { reported }\end{array}$ & $\begin{array}{l}3.4 \pm 1.1 \\
13.2 \pm 0.9\end{array}$ & $\begin{array}{l}\text { Antiviral therapy } \\
+ \text { vitamin } C\end{array}$ & $\begin{array}{l}\text { Antiviral } \\
\text { therapy }\end{array}$ & $\begin{array}{l}\text { Total efficacy }+ \text { symptom } \\
\text { improvement }\end{array}$ \\
\hline Gao [25] & 2014 & $39 / 39$ & $\begin{array}{l}\text { Not } \\
\text { reported }\end{array}$ & $\begin{array}{l}\text { Not } \\
\text { reported }\end{array}$ & $3.5 \pm 1.0$ & $\begin{array}{l}\text { Antiviral therapy } \\
+ \text { vitamin C }\end{array}$ & $\begin{array}{l}\text { Antiviral } \\
\text { therapy }\end{array}$ & $\begin{array}{c}\text { Total efficacy }+ \text { symptom } \\
\text { improvement }\end{array}$ \\
\hline Sun [26] & 2016 & $42 / 36$ & $27 / 15$ & $\begin{array}{c}\text { Not } \\
\text { reported }\end{array}$ & $\begin{array}{l}41.7 \pm 3.5 \\
/ 40.0 \pm 3.8\end{array}$ & $\begin{array}{l}\text { Antiviral therapy } \\
\text { + vitamin C }\end{array}$ & $\begin{array}{l}\text { Antiviral } \\
\text { therapy }\end{array}$ & Total efficacy \\
\hline Liu [27] & 2007 & $50 / 50$ & $31 / 19$ & $28 / 22$ & Not reported & $\begin{array}{l}\text { Antiviral therapy } \\
\text { + vitamin C }\end{array}$ & $\begin{array}{l}\text { Antiviral } \\
\text { therapy }\end{array}$ & $\begin{array}{c}\text { Total efficacy }+ \text { symptom } \\
\text { improvement }\end{array}$ \\
\hline $\begin{array}{l}\mathrm{Li} \text { and } \\
\text { Wang [28] }\end{array}$ & 2016 & $39 / 39$ & $22 / 17$ & $21 / 18$ & $\begin{array}{l}39 \pm 2.63 \\
138 \pm 2.14\end{array}$ & $\begin{array}{l}\text { Antiviral therapy } \\
+ \text { vitamin } C\end{array}$ & $\begin{array}{l}\text { Antiviral } \\
\text { therapy }\end{array}$ & Total efficacy + side effects \\
\hline Liang [29] & 2016 & $42 / 42$ & $22 / 20$ & $24 / 18$ & $\begin{array}{c}36.8 \pm 8.1 \\
137.1 \pm 7.5\end{array}$ & $\begin{array}{l}\text { Antiviral therapy } \\
\text { + vitamin C }\end{array}$ & $\begin{array}{l}\text { Antiviral } \\
\text { therapy }\end{array}$ & Total efficacy + side effects \\
\hline $\operatorname{Lin}[30]$ & 2015 & $54 / 54$ & $35 / 19$ & $34 / 20$ & $\begin{array}{l}38.9 \pm 15.8 \\
/ 38.3 \pm 16.9\end{array}$ & $\begin{array}{l}\text { Antiviral therapy } \\
\text { + vitamin C }\end{array}$ & $\begin{array}{l}\text { Antiviral } \\
\text { therapy }\end{array}$ & Total efficacy + side effects \\
\hline
\end{tabular}

TABLE 2: Cochrane Collaboration's tool for assessing the risk of bias for the comparison of vitamin C plus antiviral therapy with antiviral therapy alone.

\begin{tabular}{|c|c|c|c|c|c|c|c|}
\hline Studies & $\begin{array}{l}\text { Random sequence } \\
\text { generation }\end{array}$ & $\begin{array}{c}\text { Allocation } \\
\text { concealment }\end{array}$ & $\begin{array}{l}\text { Blinding of participants } \\
\text { and personnel }\end{array}$ & $\begin{array}{l}\text { Blinding of } \\
\text { outcome } \\
\text { assessment }\end{array}$ & $\begin{array}{l}\text { Incomplete } \\
\text { outcome data }\end{array}$ & $\begin{array}{l}\text { Selective } \\
\text { reporting }\end{array}$ & $\begin{array}{l}\text { Other } \\
\text { bias }\end{array}$ \\
\hline Fan 2016 [21] & Unclear & Unclear & Unclear & Unclear & Low risk & Low risk & Unclear \\
\hline $\begin{array}{l}\text { Gao and Wang } \\
2014[22]\end{array}$ & Unclear & Unclear & Unclear & Unclear & Low risk & Low risk & Unclear \\
\hline Li 2017 [23] & Low risk & Unclear & Unclear & Unclear & Low risk & Low risk & Unclear \\
\hline Wu 2015 [24] & Unclear & Unclear & Unclear & Unclear & Low risk & Low risk & Unclear \\
\hline Gao 2014 [25] & Low risk & Unclear & Unclear & Unclear & Low risk & Low risk & Unclear \\
\hline Sun 2016 [26] & Unclear & Unclear & Unclear & Unclear & Low risk & Low risk & Unclear \\
\hline Liu 2007 [27] & Unclear & Unclear & Unclear & Unclear & Low risk & Low risk & Unclear \\
\hline $\begin{array}{l}\mathrm{Li} \text { and Wang } \\
2016[28]\end{array}$ & Unclear & Unclear & Unclear & Unclear & Low risk & Low risk & Unclear \\
\hline Liang 2016 [29] & Low risk & Unclear & Unclear & Unclear & Low risk & Low risk & Unclear \\
\hline $\operatorname{Lin} 2015$ [30] & Unclear & Unclear & Unclear & Unclear & Low risk & Low risk & Unclear \\
\hline
\end{tabular}

$(\mathrm{MD}=-15.84,95 \%$ CI $(-17.02,-14.66), P<0.00001)$ than the antiviral therapy alone group (Figure 3 ).

3.4.3. Average Time for Healing. The average time for healing was reported in five trials [21, 23-25, 27] involving 440 patients. Due to high heterogeneity (Cochrane $Q$ test $=$ 72.49 , df $\left.=4, P<0.00001, I^{2}=94 \%\right)$, meta-analysis was performed using the random-effects model, showing a significant difference $(\mathrm{MD}=-9.60,95 \%$ CI $(-14.98,-4.22)$,
$P=0.0005)$ between the vitamin $\mathrm{C}$ supplementation group and the antiviral therapy alone group. (Figure 4).

3.4.4. Adverse Events. Three of the 10 studies reported adverse events. There was no statistical difference between the treatment group and the control group $(P=0.18)$.

$\mathrm{Li}$ and Wang [28] showed that the incidence of mild diarrhea was $2.56 \%$ in the treatment group, while the incidence of anorexia and mild diarrhea was $7.69 \%$ in the control group $(P>0.05)$. 


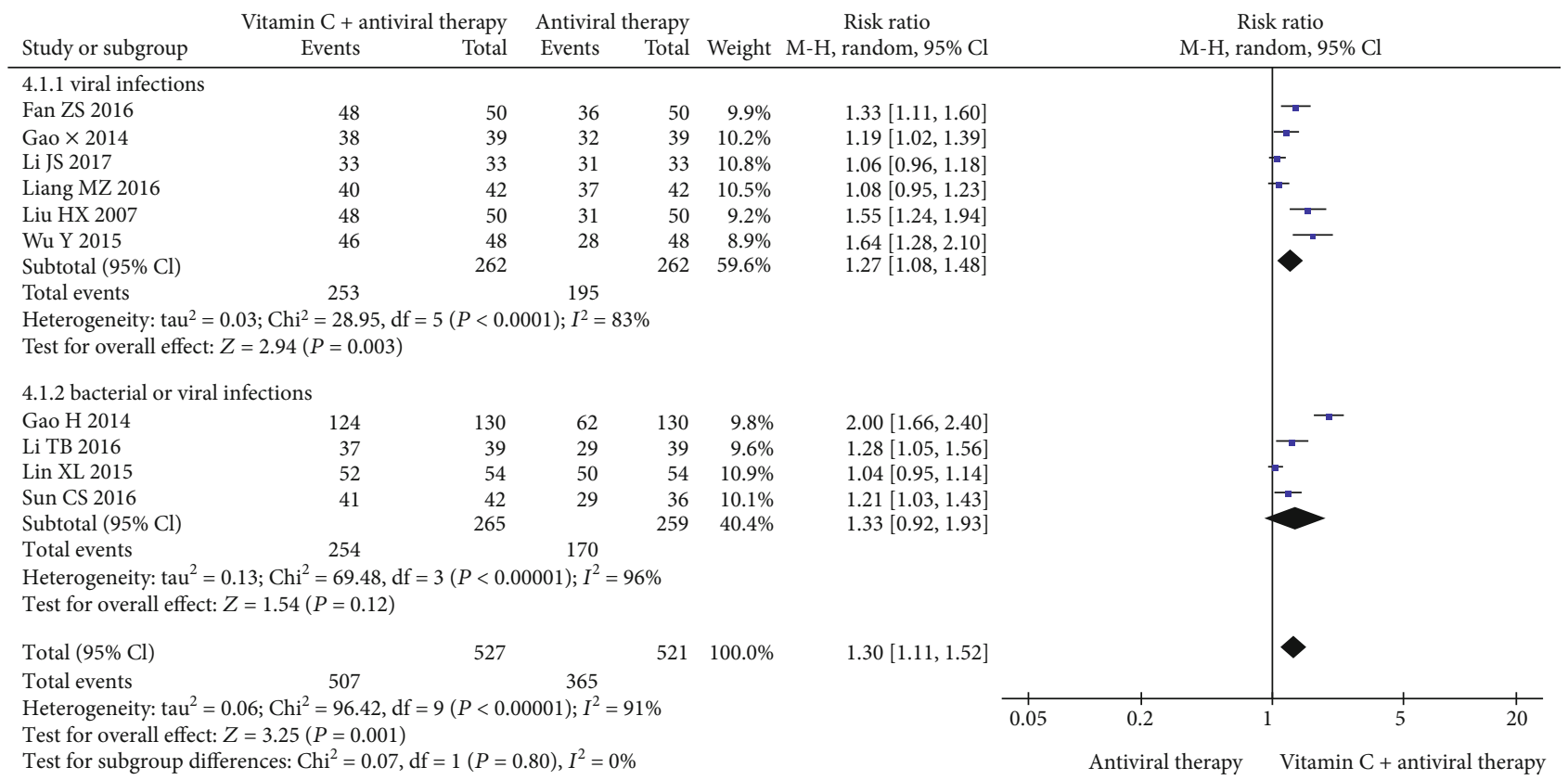

FIgURE 2: Forest plot of the meta-analysis of total efficacy.

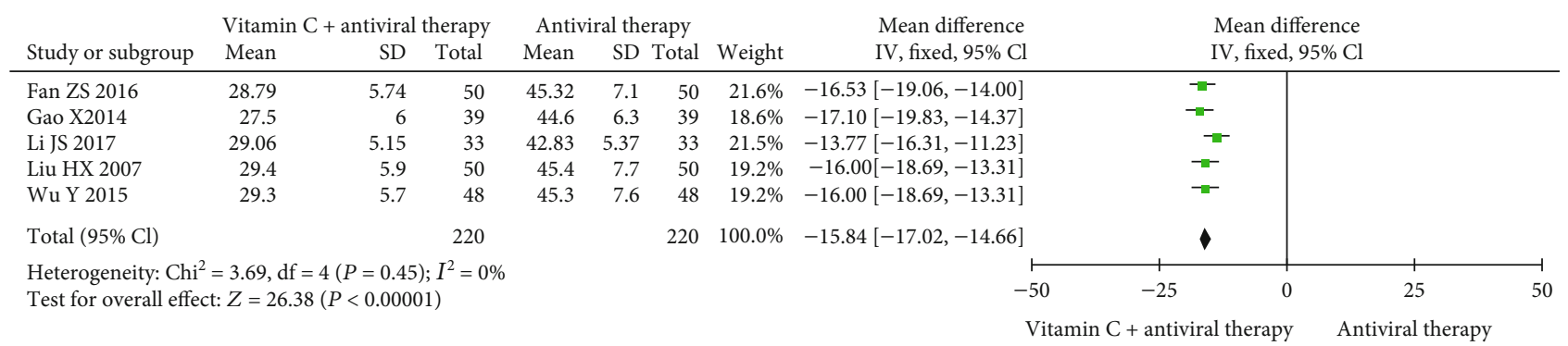

FIGURE 3: Forest plot of the meta-analysis of average time for symptom amelioration.

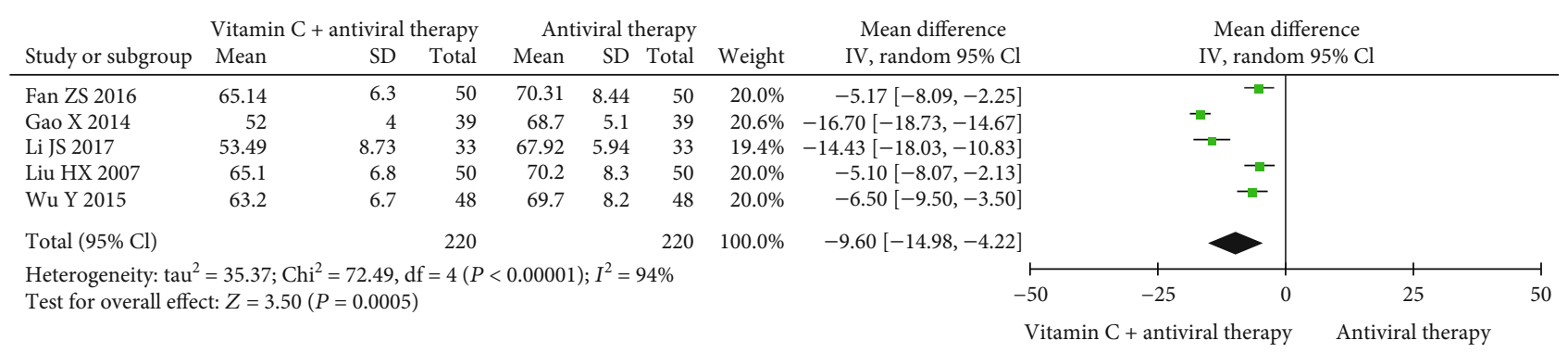

FIGURE 4: Forest plot of the meta-analysis of average time for healing.

There were two cases of rash and three cases of pruritus in the control group, and two cases of rash as well as one case of soreness in the treatment group. The incidence rate of adverse events was $11.90 \%$ and $7.14 \%$, respectively, with no statistical significance $(P>0.05)$ [29].

As reported in Fan's study [21], one case of rash occurred with antiviral therapy alone.

3.4.5. Funnel Plot. Visual inspection of the funnel plot was conducted to detect publication bias of all studies. Each study was represented by a circle, while vertical lines represented the pooled effect. There was a publication bias, as summarized in Figure 5.

\section{Discussion}

4.1. Efficacy Assessment of Vitamin C. We show strong evidence that vitamin $\mathrm{C}$ is important for the prevention and treatment of common cold. Vitamin $\mathrm{C}$ helps to relieve patients from coughing and catarrh symptoms, through its antihistaminic action, decrease of 5-hydroxytryptamine, or synthesis of prostaglandins [24, 31-33]; in addition, vitamin 


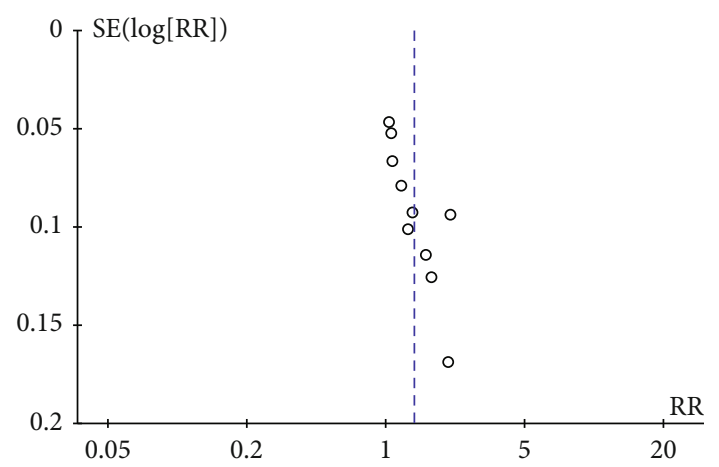

Figure 5: Funnel plot of publication bias for the comparison of vitamin $\mathrm{C}$ plus antiviral therapy with antiviral therapy alone.

C stimulates and enhances immunological functions and assists to virus killing in the pathways by scavenging free radicals and supplying energy for cells [34-38].

Based on immunity, vitamin C contributes to the prevention and treatment of common cold in four ways. First, vitamin $C$ is a constituent of white blood cells, which fight diseases through engulfment and phagocytosis of pathogens. During common cold, supplementation with vitamin C markedly increases the capability to resist pathogenic bacteria and shortens the disease course $[39,40]$. Second, adequate vitamin $\mathrm{C}$ can assist with the production of nutrients such as proteins, lipids, selenium, vitamin $\mathrm{A}$, and vitamin $\mathrm{E}$, through reduction reaction. Nutrients then support production and activity of antibodies and ensure proper metabolism of cells [41]. In addition, vitamin C participates in specific immune responses with two different approaches, namely, T-cellmediated immunity and B-cell-mediated humoral immunity [42-46]. Furthermore, C1 synthesis might be associated with serum vitamin $\mathrm{C}$ levels, whereas synthesized C1q molecules induce the classical pathway of complement activation after binding to $\operatorname{IgGC}_{\mathrm{H}} 2$ and $\operatorname{IgMC}_{\mathrm{H}} 3$ domains, thereby enabling nonspecific immune defense [47]. Last but not the least, vitamin $\mathrm{C}$ enhances immunity through phagocyte activation. The effects of vitamin $\mathrm{C}$ on phagocytes are exerted through three different mechanisms: direct impact on phagocytosis, influence on cell migration and chemotaxis, and protection of phagocytes [48, 49].

In our meta-analysis, the total efficacy $(\mathrm{RR}=1.27,95 \%$ CI $(1.08,1.48), P=0.003)$, the time for symptom amelioration $(\mathrm{MD}=-15.84,95 \% \mathrm{CI}(-17.02,-14.66), P<0.00001)$, and the time for healing ( $\mathrm{MD}=-9.60,95 \%$ CI $(-14.98$, -4.22), $P=0.0005)$ were all better after vitamin $C$ supplementation than after antiviral therapy alone. Due to the high heterogeneity in the comparisons of efficacy and healing time, we cannot safely conclude that vitamin $\mathrm{C}$ is a complementary treatment to antiviral therapy, although it is clear that it helps to improve cold symptoms. More high-quality RCTs are required in the future, to prove the efficacy of vitamin C supplementation in treating common cold.

4.2. Rational Use of Medications. During the process of literature selection and data analysis, we revealed an interesting phenomenon: patients with mild cold in Europe and the United States are requested to rest in bed, drink fluids, and supplement with vitamin C, while patients in China tend to be prescribed antiviral drugs and even antibiotics rather than vitamin C.

An investigation conducted by the Chinese Asthma Alliance and Evidence-Based Center of China in 2010 indicated that the knowledge on the treatment of common cold varied among clinics, due to the varying levels of healthcare and education in different areas of China. When common cold occurs, antibiotics may be the first choice to resolve inflammation and relieve patients from symptoms. The irrational use of antibiotics occurs especially in primary hospitals and in children [50-52]. Since evidence has demonstrated that antibiotics are ineffective for acute URTI (AURTI) and common cold [53-55], antibiotics are not recommended [56-58].

Additionally, misinterpretation of the function and usage of ribavirin may occur in some clinics. Ribavirin is generally regarded as an antiviral therapeutic for the treatment of AURTI in China [59]; however, it is strictly limited to the treatment of chronic hepatitis C and children's severe LRTIs caused by respiratory syncytial virus [59-62]. The newly published "Essential Medicines List" (version 2017) [63] summarizes clear guidelines for ribavirin, which is typically used for the treatment of viral hemorrhagic fevers and hepatitis C.

Finally, irrational use of the combinations of OTC cold medications often occurs, due to the lack of medication guidance or elementary knowledge of hygiene, thus potentially leading to increased costs, drug interactions, more side effects, and administration of unnecessary drugs $[15,64,65]$.

The following advice is recommended for the treatment of cold: (1) OTC medications are recommended for relieving patients from symptoms instead of antiviral therapy [66] (for example, a first-generation antihistamine and decongestant preparation is recommended for patients with acute cough associated with common cold [56, 67]); (2) oral medicine, rather than intravenous infusion, is the first treatment choice [66]; (3) antibiotics should be used only when there is evidence of secondary bacterial infection; (4) cough and cold medicine for young children should include acetaminophen or ibuprofen instead of aspirin, due to risk of Reye's syndrome; packaging of cough and cold medicines for young children should display a warning similar to that recommended by the US Food and Drug Administration [68]; and (5) traditional Chinese medicine is recommended [69].

4.3. Limitation. There were some limitations to our study. First, the 10 RCTs comparing antiviral therapy alone with vitamin $\mathrm{C}$ supplementation should have been more normative and clear to minimize bias. There was no description of the generation of random sequence in most trials, and it was not discussed whether the studies were double-blinded or whether allocation was concealed. We sincerely advocate for standardization of study theses and increased efforts to improve the quality of methodologies. Furthermore, publication bias may result in misleading outcomes. 


\section{Conclusion}

Supplementation with vitamin $\mathrm{C}$ during the treatment of common cold could benefit symptom improvement.

$\begin{array}{ll}\text { Abbreviations } \\ \text { PubMed: } & \text { National Library of Medicine } \\ \text { CNKI: } & \text { China National Knowledge Infrastructure } \\ \text { URTI: } & \text { Upper respiratory tract infection } \\ \text { LRTI: } & \text { Lower respiratory tract infection } \\ \text { AURTI: } & \text { Acute upper respiratory tract infection } \\ \text { MOOSE: } & \text { Systematic Reviews of Observational Studies } \\ \text { PRISMA: } & \text { Preferred Reporting Items for Systematic Reviews } \\ & \text { and Meta-Analyses } \\ \text { RCTs: } & \text { Randomized controlled trials } \\ \text { PCR: } & \text { Polymerase chain reaction } \\ \text { SD: } & \text { Standard deviation } \\ \text { RR: } & \text { Risk ratio } \\ \text { CI: } & \text { Confidence intervals } \\ \text { MD: } & \text { Mean difference } \\ \text { TCM: } & \text { Traditional Chinese medicine. }\end{array}$

\section{Data Availability}

Data are all contained within the paper.

\section{Conflicts of Interest}

The authors declare no conflict of interests regarding the publication of this paper.

\section{Authors' Contributions}

W.L.Z. and Y.Z. conceived and designed the study. H.E.B and H.W.W. analyzed data. L.R. contributed reagents/materials/analysis tools. L.R., W.L.Z., and Y.Z. wrote the manuscript. All authors have read and approved of the final manuscript. Li Ran and Wenli Zhao contributed equally to this study.

\section{Acknowledgments}

The authors thank Dr. Bin Wang for assistance with data extraction. This project was supported by the Construction Project of Cultivate Discipline of Chinese Preventive Medicine of State Administration of Traditional Chinese Medicine of the People's Republic of China (2012 (170)) and the Key Project of Comprehensive Investment in Food Hygiene and Nutrition of the Tianjin 13th Five-Year Plan. This study was also supported in part by the Scientific Research Project of Tianjin Health Commission (Number: 2019007).

\section{References}

[1] B. Arroll, "Common cold," BMJ Clinical Evidence, vol. 2011, p. 1510, 2011.

[2] R. Eccles, "Understanding the symptoms of the common cold and influenza," The Lancet Infectious Diseases, vol. 5, no. 11, pp. 718-725, 2005.
[3] T. Heikkinen and A. Järvinen, "The common cold," Lancet, vol. 361, no. 9351, pp. 51-59, 2003.

[4] A. D. Hay, E. Anderson, S. Ingle, C. Beck, and W. Hollingworth, "Respiratory tract infections in children in the community: prospective online inception cohort study," Annals of Family Medicine, vol. 17, no. 1, pp. 14-22, 2019.

[5] T. J. Bramley, D. Lerner, and M. Sarnes, "Productivity losses related to the common cold," Journal of Occupational and Environmental Medicine, vol. 44, no. 9, pp. 822-829, 2002.

[6] J. Hellgren, A. Cervin, S. Nordling, A. Bergman, and L. O. Cardell, "Allergic rhinitis and the common cold-high cost to society," Allergy, vol. 65, no. 6, pp. 776-783, 2010.

[7] P. F. Adams, G. E. Hendershot, and M. A. Marano, "Current estimates from the national health interview survey, 1996," Vital and Health Statistics. Series 10, Data from the National Health Survey, vol. 200, pp. 1-203, 1999.

[8] D. M. L. Klingeleers, Polylnosinic-polycytidylic acid (poly (i: c)) formulations for the treatment of upper respiratory tract infections: U.S. Patent Application 15/034,347, 2014.

[9] A. M. Fendrick, A. S. Monto, B. Nightengale, and M. Sarnes, "The economic burden of non-influenza-related viral respiratory tract infection in the United States," Archives of internal medicine, vol. 163, no. 4, pp. 487-494, 2003.

[10] R. B. Turner, "Epidemiology, pathogenesis, and treatment of the common cold," Annals of Allergy, Asthma \& Immunology, vol. 78, no. 6, pp. 531-540, 1997.

[11] N. G. Papadopolos, M. Xatzipsalti, and S. L. Johnson, The common cold. Respiratory Infections, p. 183, 2006.

[12] G. H. Ren, “The market for cold medicine in 2008," China Drug Store, vol. 8, pp. 58-59, 2009.

[13] C. F. Sheng, "The treatment and control of epidemic disease," Guide of China Medicine, vol. 9, no. 31, pp. 475-476, 2011.

[14] J. Y. Xu, X. Y. Hu, and S. A. Ren, Modern diagnosis and treatment of chronic obstructive pulmonary disease, vol. 1, China Medical Science Press, Beijing, 2001.

[15] K. Collins, "Seasonal mortality in the elderly," in Society for the Study of Human Biology. Symposium 35: Seasonality and Human Ecology, S. Ulijaszek and S. Strickland, Eds., pp. 135148, Cambridge University Press, Cambridge, 1993.

[16] R. W. Stout and V. Crawford, "Seasonal variations in fibrinogen concentrations among elderly people," The Lancet, vol. 338, no. 8758, pp. 9-13, 1991.

[17] S. Johnston and S. Holgate, "Epidemiology of viral respiratory infections," in Viral and Other Infections of the Human Respiratory Tract, S. Myint and D. Taylor-Robinson, Eds., pp. 1-38, Chapman \& Hall, London, 1996.

[18] S. Pradhan and A. C. Jauhari, A study of antibiotics used in adult respiratory disorders in Kathmandu and Bhaktapur, 2007.

[19] D. F. Stroup, J. A. Berlin, S. C. Morton et al., "Meta-analysis of observational studies in epidemiology: a proposal for reporting. Meta-analysis Of Observational Studies in Epidemiology (MOOSE) group," JAMA, vol. 283, no. 15, pp. 2008-2012, 2000.

[20] D. Moher, A. Liberati, J. Tetzlaff, D. G. Altman, and PRISMA Group, "Preferred Reporting Items for Systematic Reviews and Meta-Analyses: the PRISMA statement," Annals of Internal Medicine, vol. 151, no. 4, pp. 264-9, W64, 2009.

[21] Z. S. Fan, "Clinical curative effect analysis of vitamin C in adjunctive therapy of early virus flu," China \& Foreign Medical Treatment, vol. 3, pp. 142-143, 2016. 
[22] H. Gao and M. H. Wang, "The analysis of the clinical efficacy of inhalation of vitamin $\mathrm{C}$ injection in the treatment of pediatric upper respiratory tract infection," World Latest Medicine Information, vol. 14, no. 1, p. 192, 2014.

[23] J. S. Li, "The clinical effects of ribavirin and vitamin C of early colds," The World Clinical Medicine, vol. 11, no. 5, p. 96, 2017.

[24] Y. Wu, "The clinical research on early colds with vitamin C," The World Clincal Medicine, vol. 9, no. 7, p. 135, 2015.

[25] X. Gao, "The observation of curative effect on early colds with vitamin C," China Practical Medical, vol. 9, no. 2, pp. 182-183, 2014.

[26] C. S. Sun, "The clinical effect of XiYanPing injection and vitamin C in the treatment of upper respiratory tract infection," Word Latest Medicine Information, vol. 16, no. 69, p. 213, 2016, 220.

[27] H. X. Liu, "Fifty cases of early colds treated with vitamin C," Medical Information, vol. 20, no. 5, pp. 837-838, 2007.

[28] T. B. Li and H. Y. Wang, "The effect of XiYanPing and vitamin $\mathrm{C}$ in the upper respiratory tract infection," Medicine and Hygiene, vol. 2, no. 7, p. 144, 2016.

[29] M. Z. Liang, "The observation of curative effect on upper respiratory tract infection with XiYanPing injection and vitamin C," Journal of North Pharmacy, vol. 13, no. 6, p. 69, 2016.

[30] X. L. Lin, "The observation of curative effect on upper respiratory tract infection with vitamin C and XiYanPing injection," Chinese Journal of Modern Drug, vol. 9, no. 24, pp. 123-124, 2015.

[31] E. Zuskin, A. J. Lewis, and A. Bouhuys, "Inhibition of histamine-induced airway constriction by ascorbic acid," Journal of Allergy and Clinical Immunology, vol. 51, no. 4, pp. 218226, 1973.

[32] C. Kónya and P. Ferdinandy, "Vitamin C: new role of the old vitamin in the cardiovascular system?," British journal of pharmacology, vol. 147, no. 2, pp. 125-127, 2006.

[33] T. M. A. ElAttar and H. S. Lin, "Effect of vitamin C and vitamin $\mathrm{E}$ on prostaglandin synthesis by fibroblasts and squamous carcinoma cells," Prostaglandins, leukotrienes and essential fatty acids, vol. 47, no. 4, pp. 253-257, 1992.

[34] K. C. Jeng, C. S. Yang, W. Y. Siu, Y. S. Tsai, W. J. Liao, and J. S. Kuo, "Supplementation with vitamins C and E enhances cytokine production by peripheral blood mononuclear cells in healthy adults," The American journal of clinical nutrition, vol. 64, no. 6, pp. 960-965, 1996.

[35] W. Prinz, J. Bloch, G. Gilich, and G. Mitchell, “A systematic study of the effect of vitamin $C$ supplementation on the humoral immune response in ascorbate-dependent mammals. I. The antibody response to sheep red blood cells (a Tdependent antigen) in guinea pigs," International journal for vitamin and nutrition research, vol. 50, no. 3, pp. 294-300, 1980.

[36] Y. N. Zeng, H. Q. Zheng, J. F. Gu et al., "Dual-emissive metalorganic framework as a fluorescent "switch" for ratiometric sensing of hypochlorite and ascorbic acid," Inorganic Chemistry, vol. 58, no. 19, pp. 13360-13369, 2019.

[37] C. S. Johnston, L. J. Martin, and X. Cai, "Antihistamine effect of supplemental ascorbic acid and neutrophil chemotaxis," Journal of the American College of Nutrition, vol. 11, no. 2, pp. 172-176, 1992.

[38] A. L. Mullins, S. P. van Rosendal, D. R. Briskey, R. G. Fassett, G. R. Wilson, and J. S. Coombes, "Variability in oxidative stress biomarkers following a maximal exercise test," Biomarkers, vol. 18, no. 5, pp. 446-454, 2013.

[39] H. S. Loh and C. W. M. Wilson, "The effect of supplementary vitamin $\mathrm{C}$ on haemopoiesis during adolescence," International Journal for Vitamin and Nutrition Research, vol. 41, no. 4, pp. 445-452, 1971.

[40] C. W. M. Wilson, H. S. Loh, and F. G. Foster, "The beneficial effect of vitamin C on the common cold," European journal of clinical pharmacology, vol. 6, no. 1, pp. 26-32, 1973.

[41] R. Figueroa-Méndez and S. Rivas-Arancibia, "Vitamin C in health and disease: its role in the metabolism of cells and redox state in the brain," Frontiers in Physiology, vol. 6, p. 397, 2015.

[42] R. Saxena and J. Kaur, "Th1/Th2 cytokines and their genotypes as predictors of hepatitis B virus related hepatocellular carcinoma," World journal of hepatology, vol. 7, no. 11, p. 1572, 2015.

[43] H. W. Kim, S. I. Cho, S. Bae et al., "Vitamin C up-regulates expression of CD80, CD86 and MHC class II on dendritic cell line, DC-1 via the activation of p38 MAPK," Immune network, vol. 12, no. 6, pp. 277-283, 2012.

[44] K. Noh, H. Lim, S. K. Moon et al., "Mega-dose vitamin C modulates $\mathrm{T}$ cell functions in Balb/c mice only when administered during T cell activation," Immunology Letters, vol. 98, no. 1, pp. 63-72, 2005.

[45] E. J. Pearce, C. M. Kane, and J. Sun, "Regulation of dendritic cell function by pathogen-derived molecules plays a key role in dictating the outcome of the adaptive immune response," Chemical Immunology and Allergy, vol. 90, pp. 82-90, 2006.

[46] A. Woo, J. H. Kim, Y. J. Jeong et al., "Vitamin C acts indirectly to modulate isotype switching in mouse B cells," Anatomy \& cell biology, vol. 43, no. 1, pp. 25-35, 2010.

[47] V. Verlhac, J. Gabaudan, A. Obach, W. Schüep, and R. Hole, "Influence of dietary glucan and vitamin $\mathrm{C}$ on non-specific and specific immune responses of rainbow trout (Oncorhynchus mykiss)," Aquaculture, vol. 143, no. 2, pp. 123-133, 1996.

[48] Z. Yong, L. Chang, Y. X. Mei, and L. Yi, "Role and mechanisms of CD4+CD25+ regulatory T cells in the induction and maintenance of transplantation tolerance," Transplant Immunology, vol. 17, no. 2, pp. 120-129, 2007.

[49] S. K. Mahapatra, S. P. Chakraborty, and S. Roy, "Immunomodulatory role of Ocimum gratissimum and ascorbic acid against nicotine-induced murine peritoneal macrophages in vitro," Oxidative medicine and cellular longevity, vol. 2011, 11 pages, 2011

[50] W. Tian and N. Ding, "Analysis of the antibiotics rational usage in patients with acute upper respiratory tract infection in emergence department," Journal of Clinical Emergency Call, vol. 13, no. 2, pp. 89-93, 2012.

[51] Y. Li, "The clinical use of antibiotic in upper respiratory tract infection," Journal of North Pharmacy, vol. 12, no. 2, p. 126, 2015.

[52] Y. Gao, "Analysis of antibiotics in pediatric patients with acute upper respiratory tract infection," Chinese Community Doctors, vol. 19, pp. 13-14, 2016.

[53] A. M. Gadomski, "Potential interventions for preventing pneumonia among young children," The Pediatric infectious disease journal, vol. 12, no. 2, pp. 115-119, 1993.

[54] B. Arroll and T. Kenealy, "Antibiotics for the common cold and acute purulent rhinitis," in Cochrane Database Systematic Reviews, vol. 2013, no. 6, Article ID CD000247, 2013. 
[55] L. Kaiser, D. Lew, B. Hirschel et al., "Effects of antibiotic treatment in the subset of common-cold patients who have bacteria in nasopharyngeal secretions," The Lancet, vol. 347, no. 9014, pp. 1507-1510, 1996.

[56] M. Simasek and D. A. Blandino, "Treatment of the common cold," American Family Physician, vol. 75, no. 4, pp. 515520, 2007.

[57] Treating the common cold, An expert panel consensus recommendation for primary care clinicians, vol. 5, no. 4, 2004, Jointly sponsored by the lllinois Academy of Family Physicians/Family Practice Education Network (IAFP/EPEN) and FnP Associates, USA, 2004.

[58] The institute of respiratory medicine of the Chinese medical association, "Diagnostic and treatment guidelines for cough (version 2009)," Chinese Journal of Tuberculosis and Respiratory Diseases, vol. 32, no. 6, pp. 407-413, 2009.

[59] J. X. Liu, B. L. Du, and L. N. Wang, "Discussion on Rivavirin," Heilongjiang Medicine and Pharmacy, vol. 36, no. 5, pp. 24-27, 2013.

[60] M. P. Manns, J. G. McHutchison, S. C. Gordon et al., "Peginterferon alfa- $2 \mathrm{~b}$ plus ribavirin compared with interferon alfa$2 \mathrm{~b}$ plus ribavirin for initial treatment of chronic hepatitis $\mathrm{C}$ : a randomised trial," The Lancet, vol. 358, no. 9286, pp. 958965, 2001.

[61] G. L. Davis, R. Esteban-Mur, V. Rustgi et al., "Interferon alfa$2 \mathrm{~b}$ alone or in combination with ribavirin for the treatment of relapse of chronic hepatitis C," New England journal of medicine, vol. 339, no. 21, pp. 1493-1499, 1998.

[62] K. Ventre and A. Randolph, "Ribavirin for respiratory syncytial virus infection of the lower respiratory tract in infants and young children," in Cochrane Database Systematic Reviews, vol. 24, no. 1, Article ID CD000181, 2007.

[63] World Health Organization, 20th Essential medicines list, 2017, http://www.who.int/medicines/news/2017/20th_ essential_med-list/en/.

[64] J. Tian, H. Chen, X. Z. Wei, S. X. Chen, L. P. Peng, and L. X. $\mathrm{Shu}$, "The analysis on the behavior and characteristics of cold patients," Journal of Pharmaceutical Practice, vol. 26, no. 2, pp. 126-128, 2008.

[65] T. S. Fang, Y. P. Huang, C. Q. Huang, Y. Chen, and J. Y. Wang, "The analysis on unreasonable use with medication in primary health service centers," Capital Medicine, vol. 14, pp. 60-61, 2014.

[66] Respiratory physicians of Chinese Medical Doctor Association and emergency physicians of Chinese Medical Doctor Association, "Expert consensus of standard diagnosis and treatment in common cold," Chinese Journal of Critical Care Medicine, vol. 32, no. 11, pp. 961-965, 2012.

[67] M. R. Pratter, "Cough and the common cold: ACCP evidencebased clinical practice guidelines," Chest, vol. 129, pp. 72-74, 2006.

[68] L. Snellman, W. Adams, G. Anderson et al., Diagnosis and treatment of respiratory illness in children and adults, Institute for Clinical Systems Improvement (ICSI), Bloomington (MN), 2013.

[69] Lung Diseases Branch of Chinese Society of Traditional Chinese Medicine/ Lung Disease Branch of Chinese Society of National Medicine, "Diagnostic and treatment t Chinese medicine in treating common cold (version 2015)," Journal of Traditional Chinese Medicine, vol. 57, no. 8, pp. 716-720, 2016. 